应列

\title{
乳癌根治手術後の皮膚弁壊死に関する検討
}

\author{
高知市立市民病院外科 小 柴 康”伊藤末喜
}

\section{A STUDY ON SKIN FLAP NECROSIS AFTER RADICAL MASTECTOMY}

Yasushi KOSHIBA and Sueyoshi ITOH

Department of Surgery, Kochi City Hospital

\section{乳癌根治手術後の皮席并塤死の発生因子について検討を行った。}

対象症例は昭和53年11月か.5の約 2 年間に高知市立市民病院外科で乳癌手術を5け，真 皮下に皮下脂肪を島状に残した比较的薄い皮成弁が作成された100例である. 皮庙弁壊死 の判定は術後 2 週間日に行い，壊死が真皮層に及んでいると考えられる場合を壊死例 之

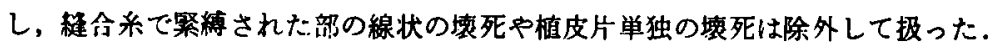

緃切開法によって手術をらけた87例では，33例（37.9\%）に壊死がみられた。年踰別に は49歳以下 $12 / 18 ， 50$ 藏以上21/39で，また肥满度との関係では肥满度 $10 \%$ 末满 $8 / 39 ， 10 \%$

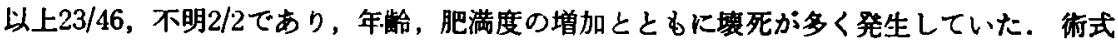

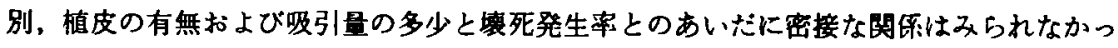
た.

次に植皮術を必要とせず張力を测定し得た27例について，乳頭の高さ，その上・下 $5 \mathrm{~cm}$ の各 3 部位の皮成并にかかる㲀力と壊死発生との関係についてみると, 張力が100g 重以 下5/28,101 200g 重5/29,201 300g 重2/15,301〜700g 重1/9であり, 張力と壊死発生 とのあいだに密接な関保はみられなかった．

植皮術を必要とした症例を含む36例の皮下䟝踓子定距離との関保では， $7.5 \mathrm{~cm}$ 末満の

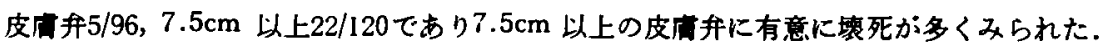

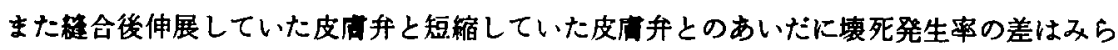

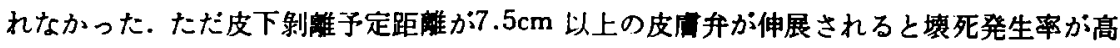
かった。

横切開法によって手術をらけたは例には壊死は1例もみられなかった。

\section{梌言}

乳癌根治手術後の早期合併症の一つに術創部皮庙并の 一部壊死がある.この問題は, 従来癌の根治性を優先す るために軽視されがちであったが，単に創治窄に要する 期間だけの問題でなく，術後併用㞠法の開始時期を遅ら せたり，患側上肢の浮尰や運動障害をひきおこすことも 考えられ軽視できない問題である. 術後皮庙并壊死の発 生には多くの因子か関与していると考えられるが，私ど むはこれらの因子について検討し，若干の知見を得たの

\footnotetext{
* 德島大学医学部外科学第 2 撛座, 専攻生
}

\section{で報告する。}

\section{研究対象および方法}

対象は昭和53年11月か 5 の約 2 年間に高知市立市民病 院外科で乳癌手術をうけた100例で，皮后并の厚さは真 皮下に皮下脂肪を島状に残した比较的薄いむのである. このうち前半の50例において主として释合時皮属并にか。 かる張力との関俰について，また後半の50例においては 皮下剩離子定距離および皮间弁の伸展状熊と皮虚弁壊死 発生との関係について調査した。

皮局弁境死の判定は術後 2 週間目に行い, 壊死が真皮 


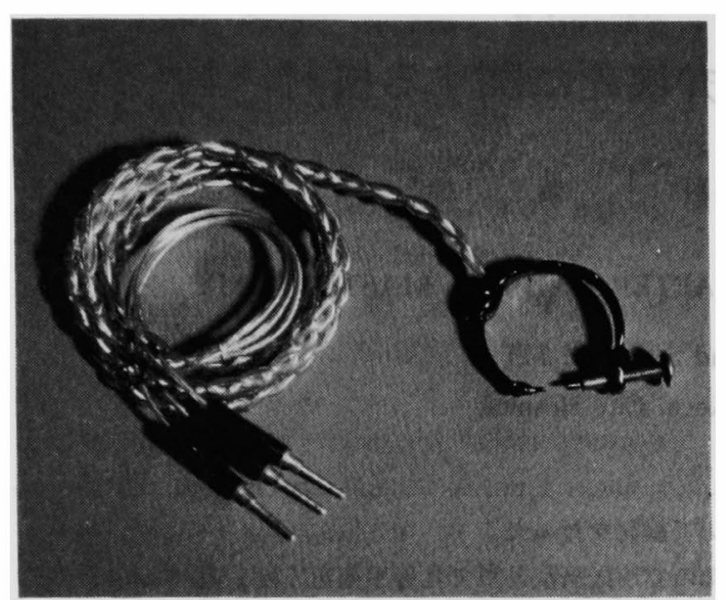

写真 1 Strain gageを用いた張力測定器具. 張 力の測定可能範囲；1 2000g 重, 最大感度; 20 $\mathrm{mV} / \mathrm{g}$ 重, 直線性; $10 \sim 1,000 \mathrm{~g}$ 重, 最大誤差; $\pm 1.2 \%$ ，增幅・記録装置；日本光電株式会社製 carrier amp RP-3

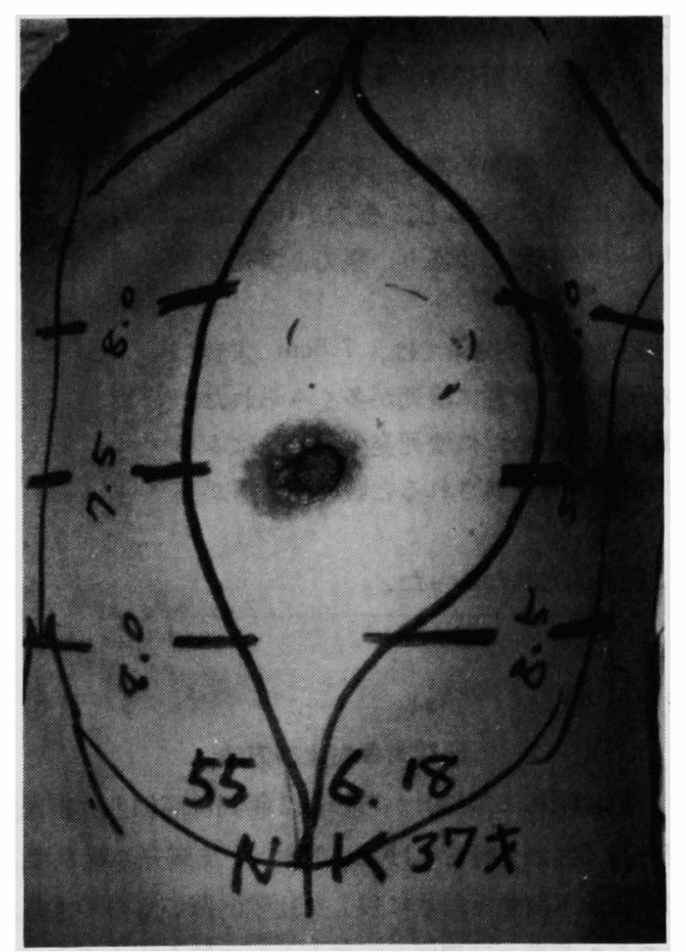

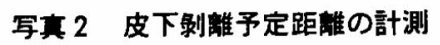

㬝に及んでいると考えられる場合を壊死例とし，いわゆ る super facial necrosis や, 䋖合糸で緊縛された部の線 状の壊死および植皮片単独の壊死は除外して扱った.
張力の測定法 : 張力の湘定は私どすの考案作製による 張力測定器具を使用した（写事 1 ). Arch の 2 点間にか かる張力を, strain gageを用い電気抵抗の変化としてと りだし，増幅して記録した。

皮膚弁の伸展状態: 手術直前に皮展切開線から皮下制 離子定線までの距離を計測し（写京 2 ），䋖合終了後同 部の皮店弁の長さを再度測定した. 後者より前者を差引 いた值を皮唐并の伸展状態とした。

これらの測定は縦切開の場合乳頭の高さ, その上・下 $5 \mathrm{~cm}$, 横切開の場合乳頭線, その内側 - 外側 $5 \mathrm{~cm}$ の皮成 弁について行った.

結果は $\chi_{2}$ 検定によって分析した.

\section{結果}

対象症例の皮唐切開法" 氏縦切開法87例, Stewart 氏横切開法13例であった。

\section{1. 镂切開法}

䌅切開法によって手術をらけた87例中壊死は33例 (37.9\%)にみられた.

1）年龄：年齡別にみると表 1 のごとく，20歳台の 2 例中 1 例を除けぱ，30歳台 $1 / 11$ (9.1\%)，40歳台10/35 (28.6\%)，50歳台12/23(52.2\%)，60歳台9/16 (56.3 \%) と，高㱓になるとともに壊死発生率 の増加がみら れ，49歳以下に比ぺ50葴以上に有意に買死が多く発生し ていた $(p<0.05)$.

表 1 年令と皮占弁壤死発生との閶係

\begin{tabular}{c|c}
\hline 年令 (オ) & 㯰死症例数 $/$ 症例数 (名) \\
\hline $20 \sim$ & $1 / 2(50.0)$ \\
\hline $30 \sim$ & $1 / 11(2.1)$ \\
\hline $40 \sim$ & $10 / 35(28.6)$ \\
\hline $50 \sim$ & $12 / 23(52.2)$ \\
\hline $60 \sim$ & $9 / 16(56.3)$ \\
\hline 計 & $33 / 87(37.9)$ \\
\hline
\end{tabular}

2）肥満度 ${ }^{2)}$ : 表 2 は肥満度と壊死発生についてみた ものである. 肥満度がー10\%末満のやせた人10例には壊 死例はなく，-10\%以上10\%未満の正常では8/29(27.6 $\%), 10 \%$ 以上 $20 \%$ 未満の体重増加では8/19 (42.1\%), $20 \%$ 以上の肥満では $15 / 27(55.6 \%)$ と肥满度の増加と ともに壊死発生率が高くなり，やせた人や正常の人に 比へ，体重増加や肥满の人に壊死が多くみられた（ $\mathrm{p}<$ 0.01 ).

3）手術術式・植皮の有無：表 3 は手術術式および初 
表 2 肥满度*と皮成并塔死発生との関保

\begin{tabular}{|c|c|}
\hline 盵満 度 & $\begin{array}{c}\text { 措死症例数/症例数 } \\
(96)\end{array}$ \\
\hline るいそう $(x<-20)$ & $0 / 2$ \\
\hline 体重掝少 $(-20 \leqq x<-10)$ & $0 / 8$ \\
\hline 正 常 $(-10 \leqq x<10)$ & $8 / 29(27.6)$ \\
\hline 体重增加 $(10 \leqq x<20)$ & $8 / 19(42.1)$ \\
\hline 肥 满 $(20 \leqq x)$ & $15 / 27(55.6)$ \\
\hline 明 & $2 / 2$ \\
\hline 計 & $33 / 87(37.9)$ \\
\hline \multicolumn{2}{|c|}{$\frac{\text { 実則体重一標售体重 }}{\text { 摽整体重 }} \times 100$} \\
\hline
\end{tabular}

表 3 手術術式・植皮の有無と皮虎并塄死発生と の関係

\begin{tabular}{|c|c|c|c|}
\hline \multirow{2}{*}{ 術 式 } & \multicolumn{2}{|c|}{ 植皮 } & \multirow{2}{*}{ 計 (\%) } \\
\hline & $(-)$ & $(+)$ & \\
\hline $\mathrm{Br}+\mathrm{Ax}$ & $7 / 14$ & $0 / 0$ & $7 / 14(50.0)$ \\
\hline 定型的乳房切断 & $13 / 34$ & $5 / 14$ & $18 / 48(37.5)$ \\
\hline 拡大根治手術 & $3 / 12$ & $5 / 13$ & $8 / 25(32.0)$ \\
\hline 計 (\%) & $23 / 60(38.3)$ & $10 / 27(37.0)$ & $33 / 87(37.9)$ \\
\hline
\end{tabular}

回手術時の植皮の有無 との関係についてみたものであ る. 術式別には非定型的乳房切断術 $7 / 14(50.0 \%)$, 定型 的乳房切断術18/48 (37.5\%), 抾大根治手術 $8 / 25$ (32.0 \%) に壊死がみられ，末た植皮の有無との関係では植 皮をしなかったのの23/60（38.3\%)，植皮を行ったもの 10/27（37.0\%）であり，術式別および植皮の有無と壊死 発生率とのあいだに有意の差はみられなかった。

4）吸引量の多少・皮成并下詝留液：術後胸壁ドレー ン上りの吸引量との関係についてみると，吸引量の多い ののに壊死が多い㑯向はみられなかった（表4）。また

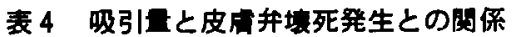

\begin{tabular}{c|c}
\hline 吸引量 $(\mathrm{ml})$ & 壊死症例数 $/$ 症例数 (\%) \\
\hline$\sim 100$ & $12 / 37(32.4)$ \\
\hline$\sim 200$ & $16 / 39(41.0)$ \\
\hline$\sim 300$ & $4 / 8(50.0)$ \\
\hline $301 \sim$ & $1 / 2$ \\
\hline 不明 & $0 / 1$ \\
\hline 計 & $33 / 87(37.9)$ \\
\hline
\end{tabular}

第刺排液などの処置を必要とした症例が 5 例あったが， 眝留部に壊死がられたのは 2 例であった，

5）張力：前半の50例中，植皮術を必要としなかった のは31例であった：このらち張力を測定し得た27例の皮 席升にかかる張力と部位別壊死発生との関係は表 5 の ごとくであった．張力が100g 重以下の皮庙升では5/28 (17.9\%), 101 200g 重では5/29(17.2\%)，201 300g 重では2/15 (13.3\%)，301〜700g 重では1/9 (11.1\%) に壊死がられ，私どもが通常植皮なしで創を䋖合閉鎖 している張力か $700 \mathrm{~g}$ 重以下の範囲では, 張力と壊死発 生とのあいだに密接な関保はみられなかった。

6）皮下制離予定距離: 同27例の皮下剝離予定距離に ついてみると，皮下剥離予定距離か $7.5 \mathrm{~cm}$ 以上の皮膚升 にのみ罗死がみられていた。

そこで後半の50例に打いては，植皮を必要とした症例 を含めて皮下劋離予定距離拉よび皮唐并の伸展状態と皮 居并壊死の発生について調査した（表 6)．綎切開法に よって手術を5けた症例は41例で，5ち測定のできなか った 5 例を除く 36 例・216 部位の皮下制離距離 との関係 についてみると, 皮下剝離予定距離か $7.5 \mathrm{~cm}$ 以上の皮 并升120部位では22部位 $(18.3 \%) に, 7.5 \mathrm{~cm}$ 末満の 皮唐并96部位では 5 部位 $(5.2 \%)$ に壊死がみられてお り，7.5cm 未満の皮并に比へ， $7.5 \mathrm{~cm}$ 以上の皮店并 に有意に壊死が多く発生していた $(p<0.01)$.

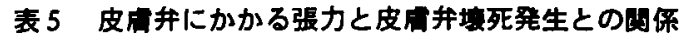

\begin{tabular}{|c|c|c|c|c|c|c|c|c|}
\hline \multirow{2}{*}{ 部位 } & \multicolumn{7}{|c|}{ 単位：グラム重） } & \multirow{2}{*}{ (詰 } \\
\hline & $\sim 100$ & -200 & -300 & $\sim 400$ & $\sim 500$ & $\sim 600$ & $\sim 700$ & \\
\hline$\frac{t}{5} \mathrm{~cm}$ & $2 / 6$ & $3 / 15$ & $1 / 4$ & $0 / 1$ & & & $0 / 1$ & $\begin{array}{r}6 / 27 \\
(22.2)\end{array}$ \\
\hline $\begin{array}{l}\text { 乳頭の } \\
\text { 高 }\end{array}$ & $3 / 9$ & $2 / 5$ & $1 / 8$ & $0 / 2$ & $1 / 2$ & $0 / 1$ & & $\begin{array}{r}7 / 27 \\
(25.9) \\
\end{array}$ \\
\hline $\begin{array}{l}\text { 下 } \\
5 \mathrm{~cm}\end{array}$ & $0 / 13$ & $0 / 9$ & $0 / 3$ & & & $0 / 1$ & $0 / 1$ & $0 / 27$ \\
\hline $\left.\begin{array}{c}\text { 計 } \\
(\mathscr{c})\end{array}\right)$ & $\begin{array}{r}5 / 28 \\
(17.9) \\
\end{array}$ & $\begin{array}{c}5 / 29 \\
(17.2) \\
\end{array}$ & $\begin{array}{r}2 / 15 \\
(13.3) \\
\end{array}$ & $0 / 3$ & $1 / 2$ & $0 / 2$ & $0 / 2$ & $\begin{array}{l}13 / 81 \\
(16.0)\end{array}$ \\
\hline
\end{tabular}




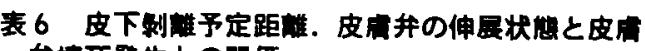
弁境死発生との的保

\begin{tabular}{|c|c|c|c|c|}
\hline \multirow{2}{*}{ 皮下剥離 } & \multicolumn{3}{|c|}{ 皮用并の伸展状悹 } & \multirow{2}{*}{ 計 (\%) } \\
\hline & 短觜 & 怵前と同し & 伸 展 & \\
\hline $7.5 \mathrm{~cm} \leqq$ & $7 / 47$ & $1 / 25$ & $14 / 48$ & $\begin{array}{l}22 / 120 \\
(18.3) \\
\end{array}$ \\
\hline$<7.5 \mathrm{~cm}$ & $0 / 28$ & $2 / 18$ & $3 / 50$ & $\begin{array}{r}5 / 96 \\
(5.2) \\
\end{array}$ \\
\hline $\begin{array}{c}\text { (訁十 } \\
(\mathscr{6})\end{array}$ & $\begin{array}{l}7 / 75 \\
(9.3) \\
\end{array}$ & $\begin{array}{l}3 / 43 \\
(7.0) \\
\end{array}$ & $\begin{array}{r}17 / 98 \\
(17.3) \\
\end{array}$ & $\begin{array}{l}27 / 216 \\
(12.5)\end{array}$ \\
\hline
\end{tabular}

表 7 撗切筒における皮下制襍予定距蜼・伸展状態

\begin{tabular}{|c|c|c|c|c|c|}
\hline \multirow{2}{*}{$\begin{array}{l}\text { 皮下剥唯 } \\
\text { 予定距誰 }\end{array}$} & \multicolumn{4}{|c|}{ 皮用井の伸展状態 } & \multirow[b]{2}{*}{ 計 } \\
\hline & 短樎 & 筒後充 & 伸展 & 不明 & \\
\hline $7.5 \mathrm{~cm} \leqq$ & 3 & 4 & 17 & 17 & 41 \\
\hline$<7.5 \mathrm{~cm}$ & 0 & 1 & 11 & 13 & 25 \\
\hline 計 & 3 & 5 & 28 & 30 & 66 \\
\hline
\end{tabular}

7）皮店升の伸展状態：皮虞并の伸展状態との関保に ついてみると，耗合後皮屈升が短縮したり，術前と同し であった 118部位では10部位 $(8.5 \%)$ に，伸展してい た98部位では17部位（17.3\%）に壊死がみられており， 両者のあいたに有意差はみられなかった。

ただ，7.5cm 以上皮下䟝離された皮原弁が伸展された ときは，その他の皮后弁に比へ壊死の発生率か $29.2 \%$ と 高かった $(\mathrm{p}<0.001)$.

\section{2. 模切荓法}

横切開法によって手術をらけたのは13例であったこ こ れらには高龄者や肥満の人も含まれており，また表 $7 に$ みられるごとく皮下剩離予定距離が $7.5 \mathrm{~cm}$ 以上で，伸展 された皮庙升が含まれているが，壊死は1例もみられな かった.

\section{考 察}

近年比較的早期の乳癌症例が增加し，根治性のみなら す機能的または美容的により優れた手術が要求されるよ 5になってきた。第33回乳宿研究会（1981年 2 月，启 敷 ${ }^{3)}$ ) において，乳癌手術に拈ける術後皮届升壊死が主 題としてとりあげられた理由は，このような時代的, 社 会的背景にあったものと考えられる.

皮后并壊死の発生には多くの因子の関与が考えられる が，皮居并の厚さなどを含めた皮原并作成法あるいは術 後管理もその重要な因子であると考えられる．またこの ことは結果の解釈にもかかわってくるので, 当科で行っ ている皮有弁の作成法，創の閉鎖法および術後管理につ いて述へる.
皮庙弁の作成法 : 綐切開法とするが横切開法とするか は，腫瘤占居部位と乳頭の位置関俰で決定している．皮

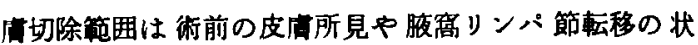

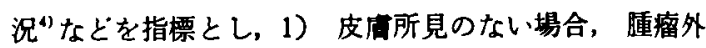
縁から2cm，2） slight dimple が認められる場合，原則 として皮庙所見のない場合に準ずるが，看舅が大きいと き $(5 \mathrm{~cm}$ 以上) や腋窩リンパ節転移が高度と考えられる とき（N1b 以上）にはより㕕範囲の皮庙切除を行5．3） 皮㡀固定所見が認められる場合，少なくとも $5 \mathrm{~cm}$ 以上 離して皮届切開線をおくことを原則としている．皮底弁 の厚さは，真皮下に岛状に皮下脂肪を残した比較的薄い 皮展升とし，皮下脂肪切除範囲は内方は正中線，外方は 後腋䆚線，上方は鎖骨下縁，下方は肋骨弓部までとして いる. この当科の皮唐并作成法は病理組織学的な検討) に基ついたものであり，局所皮度再発を指標とした 5 年 予後の面からみてむ ${ }^{6)}$ 十分な妥当性をむつむのであると 考えている.

㓣の閉鎖法：植皮が必要かど5かの決定は 2 号絹米で 皮店并を無理なく寄せられるかどらかを判断の目安とし ている，植皮が必要と决定されたときの採皮部位は， Trimble 法またはその变法による余㮃皮庙を利用するこ とが多いが，皮饮損部が広䈖な場合は同側大腿前面上 り電動式ダーマトームを用い採皮している.ト゚レーンは 手術野の外側に 1 本扰き，㩲带用持続吸引ユニットに接 続し皮店并下貯留液に対処している．植皮術を行った場 合は低压持続吸引器 $(15 \mathrm{~cm}$ 水柱) を使用する.このド レーンは術後 $2 \sim 3$ 日目に抜去する. また㧱の程合閉鎖 の直前に晹線を用いて，皮应并と肋間筋のあいたに固定 を行っている.

術後管理：術直後よりさばきガーゼを用い手術野を压 迫ぎみに固定し，さらに王迫を確実にし局所の安静を保 つため圧迫胸带”を装着する． 術後 3 時間目に包交を行 い，皮庙弁下に貯留液を認める場合にはロールガーゼで 圧出する. その後 4 日間は包交をしない，術後 5 日目に

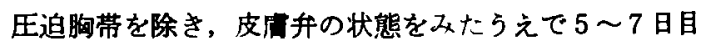

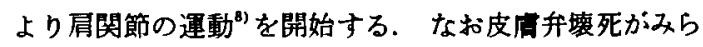
れた場合，今回㙘死例から除外した取扱った释合縁の線 状の壊死は再繾合を，㕕籍な場合は積極的に 2 次植皮術 を行っている.

以上のよ5な手術之術後管理をらけた症例の塿死の発 生状況についてみると， Stewart 横切開では広範囲の壊 死は 1 例むみられなかった。しかし第33回乳癌研究会了 ンケート集計”にによ扎ば，皮底切開の形と皮间并填死の 
発生率に余り差がないと考えている施設が44/62（71.0 \%) あり，自検例では横切開の症例数が少ないので今後 の愉討をまたねばならない，現在当科でる横切開症例が 增えつつあるが，上方と下方の皮下㔀崔の際術野がポケ ット状に濯くなり皮下脂肪切除筙囲を確保するのに困難 を感ナ゙る場合があり，術者と助手1名の少ない人数で手 術をしている当科のよらな施設では，原則として絽切開 を第 1 選択とすべきであろらと考える.

次に㙂切開法によって手術を5けた87例についてみる と33例（37.8\%）に壊死がみられた，皮庙并壊死の発生 に影辢をおよほすと考えられた諸因子のらち，年龄，肥 满度および皮下制離予定距離とのあいだに有意差がみら れた. 皮庙弁の壊死は終局的には血流または血行再開の 不良に起因すると考えられるが ${ }^{10)}$ ，高龄者では皮庙の萎 摍がおこり，また肥满の人では皮下剝離距離の長い皮局 升が多くなり，血流または血行再開不良の状態がおり 易くなるためであろらと推测された。手術術式間，植皮 の有無, 吸引量の多少とのあいたには密接な関俰はみら れなかった．皮后弁下に貯留液がらられた症例が 5 例あ ったが，5ち3 例は腋窝にちかい皮店升下にンンハ液の 眝留がみられたもので同部皮慮并の壊死はみられ寸゙，他 の 2 例は耗合縁ちかくに血液の眝留がみられたもので眝

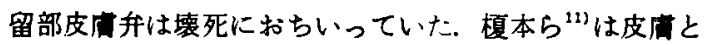
胸壁のあいたにたまる眝留液を重視しているが，血流が

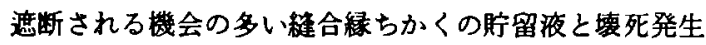
との関係が示咬された，皮庙并にかかる張力は従来かな り大きな因子とされているが，それはど重要な因子では ないと考えられた，現在医療用 2 号絧系の引張り強度は

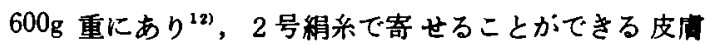
并では張力の影穆はほとんど考えなくてよい，また皮下 虽離距離か $7.5 \mathrm{~cm}$ 未満の短かい皮席弁では，皮庙并が伸 展されてb皮应弁壊死には関俰ないと考えられた。

以上の結果より綐切開後の皮店并壊死防止対策を考文 てみた，皮庙升壊死の発生と密接な関係がみられた因子 のらち年龄および肥満度は患者側要因であり，壊死がお こり易いことを念頭におきき皮庙并を要護的に扱らはかに 対策はたてられない，皮下剩離距離か $7.5 \mathrm{~cm}$ 以上の皮

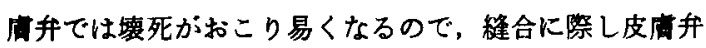
に余裕かあれは $7.5 \mathrm{~cm}$ 以上の皮有并を短切する. また $7.5 \mathrm{~cm}$ 以上の皮風并が伸展されると極めて壊死が発生 し易くなるので伸展されることがないように注意し，そ れです伸展される場合には積極的に長い皮间弁を $7.5 \mathrm{~cm}$ 未満に切除短蹜し大きな植皮片で覆らことも必要である
らと考えられた。

\section{結論}

最近の約 2 年間に当科で乳瘦根治手術をうけ，真皮下 に島状に皮下脂肪を牫した比較的薄い、皮应并が作成され た100例を対象に，皮而弁壇死の発生因子について検討 し以下の結論を得た。

1）䊀切開法では87例中33例 (37.9\%) に壊死がみら れ，年龄，肥満度および皮下剥離予定距䧺とのあいたに 密接な関係がみられた。 また術式別，植皮の有無，吸引 量の多少，皮底并にかかる張力および䋖合後皮庙弁の伸 展状態は従来いわれているほど重要な因子でないと考え られた。

2）横切開法の13例には厇範囲の罗死はみられなかっ t.

本論文の要旨は第 42 回日本臨床外科医学会総会（1980 年11月，髅岡）扰上び第33回乳癌研究会（1981年2月，

會㪙)で発表したむのである。

的辞：稿を終ろに臨み、御校閲いたたきました徳島大 学医学部外科学第 2 請座井上権治教授、張力测定器具の 製作および張力測定に際し多大な御協力をいただきまし た高知市立市民病院麻醉科平野襀造博士に深碀いたしま す.

\section{引用女献}

1）木本諴二監修：現代外科学大采，29，p. 193， 中山書店, 東京 1968.

2）高檽忠雄, 大島良雄監修: 臨休内科全書, 7,p. 145, 金原出版, 東京. 1971 。

3）第33回乳癌研究会プログラム，1981.

4) 乳癌研究会編：乳癌取扱い規的 (第 4版), 金 原出版, 東京, 1976.

5) 伊藤末喜 : 多数切片標本による乳癌の局所進展 に関寸る研究, 日外会誌, 73:776, 1972.

6) 小柴 康: 孚癌根治手術後の局所再発に関する 臨朱的检討, 日臨外会誌, $42: 6,1981$.

7）酒井く2子，大崎佐恵子，中西美咅他：乳癌患 者の術前・術後の看護, 王迫胸帯使用の 1 症例 （37藏)をとおして，臨床愁議，6：1430，1980.

8) 久保完治：第19回乳癌研究会参考資料, 乳癌術 後管理, 機能回復, 千葉 1974 .

9)第33 回乳癌研究会 フンケート集計， p.9， 1981 .

10) Myers, M.B., Brock, D. and Cohn, I. Jr.: Prevention of skin slough after radical mastectomy by the use of vital dye to delineate devascularized skin. Ann Surg., 173: 920, 1971.

11）榎本耕治, 阿部命彦：皮眉䋖合法一乳癌手術, 臨外, 30:1089, 1975 .

12）草間 悟編集 企画：外科 MOOK 4, p. 4, 金原出版, 東京, 1978. 